\title{
Differenz
}

Revista internacional de estudios heideggerianos y sus derivas contemporáneas

AÑO 5, NÚMERO 4: JULIO DE 2018. e-ISSN 2386-4877 - DOI: 10.12795/Differenz.2018.i04.04

[pp. 61-75]

Recibido: 14/05/2018

Aceptado: 05/06/2018

\section{The possibility for a practical view of ethics: Husserl and Heidegger on the philosophy of law}

\author{
Manuela Massa \\ Martin-Luther-University Halle (Saale)
}

\begin{abstract}
:
This contribution centres on the practical view of ethics and its connection with the philosophy of law as it is portrayed in the works of Edmund Husserl and Martin Heidegger. According to these two philosophers, ethics determines both the expectations for human behaviour, as well as their obligations to society. In carrying out this analysis, I consider the function of law and then its regulated function among individuals and the state. Thus, I show how the individual's orientation in the context of society makes an ethical statement, determined by humans' actions throughout their existence.
\end{abstract}

Keywords: Law; intentionality; possibility; necessity; ethics.

\section{Something like a "philosophy of law" by Husserl and Heidegger?}

It is undeniable that neither Heidegger nor Husserl wrote a work entitled: "Law" throughout their philosophical careers. Given this oversight, philosophical and juridical research has not made much progress in this direction to date. This is due in large part to the fact that 
most interpreters of Husserl and Heidegger's thought consider the philosophy to concern only phenomenology and the notion of being, something that excludes juridical theory and much of its practical application.

As a consequence, every discussion of the problem of law, and of its connection to ethics in the works of both philosophers, is absent. The philosophical research tradition focusses primarily on detecting nationalist traces in Heidegger's thought, while Husserl's work is examined repeatedly with respect to his philosophy's genetic motifs which correspond to transcendental idealism. As a result, every practical application of both thinkers' thoughts is obliterated. Nevertheless, it is possible to discover a kind of reflection in some of their main works, one focused on the meaning of the "law" and its regulated function among individuals and the state ${ }^{1}$.

In order to arrive at the concept of "law" in the philosophy of Husserl and Heidegger and its use, we might first ask: how is law to be understood and how might it be defined? Once these aspects have been clarified, it will be possible to get an overview of its use and application, as systematized from both thinkers' political conceptions. Throughout this work I will make reference to H. L. A. Hart's The Concept of Law in which the author suggests a good way to shirk off the difficulty surrounding the meaning of law, given that Hart emphasises the obstacles that come to the fore when one attempts to define the law in a permanent or definitive way. The difficulty that concerns the definition of law stems from two concerns that Hart identifies as follows:

1. International law lacks a legislature and compliant states cannot be brought before international courts without their prior consent;

2. It is not a peculiarity of complex terms like 'law' and 'legal system' that we are forced to recognize both clear standard cases and challengeable borderline cases ${ }^{2}$.

These remarks by Hart provide the opportunity to underline how the concept of law does not follow a standard or something like a "reminder of what is already familiar";

1 At this point it has to be point out the works of Sophie Loidolt. Cf. LOIDoLT, Sophie: "Anspruch und Rechtfertigung: Eine Theorie des Rechtlichen Denkens im Anschluss an die Phänomenologie Edmund Husserls". Phaenomenologica 191. Dordrecht: Springer, 2009. For the approach to Heidegger's philosophy of law, cf. MASSA, Manuela. "Selbstbestimmung und Daseinsbefreiung: Annäherungen an einen Rechtsbegriff in Heideggers Frühphilosophie in Perspektive mit Heidegger", Gerhard thonauser (Ed.), in Perspektiven mit Heidegger: Zugänge - Pfade - Anknüpfung. Berlin: Karl Alber Verlag, 2017, 147-162.

2 Cf. HART, Herbert Lionel Adolphus. The Concept of Law. Clarendon Law Series. Oxford: Clarendon, 1978,4 
instead, its most general feature shows the way according to which some aspects of human conduct have to be considered as obligatory ${ }^{3}$. At this point one might be ask: what can be thought of as obligatory in the context of society? What has to be questioned here is the mutual character of duties in the form of an individual's moral conduct. Assuming that the problem of law starts from a moral assumption, and that the prescriptions thereafter ascribe this to the human being ${ }^{4}$, then it may be further asked if any moral theory allows for the existence of law, as a form of right which incorporate faculties, and which assumes a norm allocated by the right of a subject. Thus, the same norms pertain to the subject of right ${ }^{5}$. But the contents of what it considers natural law is different again, and this modification depends on those same individuals and upon the historical context to which they refer. However, something remains constant in this construction: there are some principles of moral behaviour that are unquestionable, even if the norms change ${ }^{6}$. Hereby, the common understanding of the law is renowned in that it can be introduced only where there is a society that is based on the relation between free will and the people, in which even the union of these terms becomes the subjects of the law ${ }^{7}$. Hence, firstly it has to be point out that the law is used to establish justice through the totality of social rules and to guarantee a code of conduct. Furthermore, what is placed on the differentiation is between and subjective and objective right. In his book Recht, contemporary philosopher Matthias Kaufmann remarks how it is not possible to find something like a subjective right in the Greek, Hebraic or roman classical traditions in the European history of law, because ius is understand in the sense of objective regulation of relationship. Thus, what concerns the natural right is different form human rights, because these are not compromised from time and causality. For this reason, right has to be understood as an objective regulation of this relationship, in which the natural law is a certain sense that is different from the human right, given that it is representative of a general, valid right ${ }^{8}$. Until the beginning of the 19th century, the philosophy of law mainly concerned itself with examinations of natural law, and accordingly defined the existing rights whereby this concept's goal

\section{Ibidem, 6.}

4 Here we might distinguish between moral and ethical. As Pfordten, $D \vee d$. points out in his in his Normative Ethik, the difference between both terms remains something linguistically structurated, while the moral remains more descriptive. Cf. Vgl. PFORDTEN, D v d. Normative Ethik. Berlin: De Gruyter, 2010, 2.

5 Cf. FAssó Guido. I/ diritto naturale. Torino: Ed. Eri, 1964, 9.

6 Ibidem, 15.

7 Cf. Agnes WULF, Die Existenziale Schuld. Der fundamentalontologische Schuldbegriff Martin Heideggers und seine Bedeutung für das Strafrecht.Berlin: Lit, 2008,6.

8 Cf. KaUfmanN, Matthias. Recht. Berlin: De Grutyer, 2016, 92. 
has always been to disclose the universal validity of the split between existing rights and wrongs.

By analysing the concept of ethics in antiquity, Husserl pursued his legal conception by questioning the meaning of objective right, given that he underlines its prescriptive character, "to this appertains the condition to be generally valid"9. Although, Husserl's legal argument shows what would happen if individuals together, namely as a community, were to realise the general form of rightness. In this domain Husserl questions: what would happen if even this became a kind of objective value for each member? Hence, his general analysis of the right splits into two possibilities which concern both its application [Geltung] and its validity [Gültigkeit]. This is the reason why Husserl problematises some specific terms such as judgments, claims and conviction, which appertain to the juridical field: his pursuit is solely to ask if these concepts ground the core of a juridical analysis; if this possibility exists, then the risk incurred even regards their theoretical assessment, something which is indicated by Husserl through his use of "the minimum" [Mindeste] ${ }^{10}$ and he is not able, since it refers to general assumption of the right and following its presupposition, to clarify its deeper meaning through the application of norms. Therefore, every advancement of the recognition testifies to the use of right and, thus, what concerns the law has to be understood in connection with the reason against which the world of individuals competes, something based only on their ethical/rights principle and their persuasion. Therefore, the right cannot be held if there is a suggestion of it serving masses of individuals; instead, it has to be recognised from the specific substance of values [Gewerteten] and desire [Erstrebten $]^{11}$.

Something similar to Husserl's understanding of law can be found in Heidegger's analysis of sociality. However, his employment of legal terms in his early works, in view of this collection of laws, differs for two reasons: even though Heidegger's analysis of the term legal is fairly "classical," since the law covers society through the fundamental analysis of existence in the world and is positioned as a legal problem, it is connected

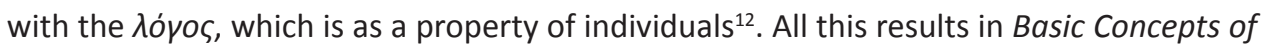
Aristotelian Philosophy; here Heidegger gives a political meaning to both kolvwvi $\alpha$ and $\lambda o ́$ os through the examination of Aristotle's first book on politics. The individuals are

9 Gewiss liegt in der Idee eines Rechts, eines in irgendeinem Sinne Sein-Sollenden, die allgemeine Gültigkeit Vgl. HUSSERL, Edmund, Einleitung in die Ethik: Vorlesungen Sommersemester 1920 und 1924. PEUCKER, Henning (ed. ) Husserliana 37. Dordrecht: Kluwer, 2004, 42.

10 Ibidem.

11 Ibidem. 43

12 MASSA M.: op. cit., p. 2 
not isolated, instead they are in a social environment with each other and they are able to speak and communicate. This standpoint is connected to Heidegger's interpretation of the Greek $\pi$ ò $\lambda$ s, that represent the concept of state which "arises out of a definite being-with-one-another"13. Meanwhile, Heidegger notes that Aristotle sees the "basis of the being of human being" in the being of $\pi \grave{\lambda} \lambda \iota \varsigma$. But the $\pi \grave{\lambda} \lambda \iota \varsigma$ represents also something more since it is according to Heidegger "the fuller sense" as the "site" of that being as Dasein which is the same human being ${ }^{14}$.

Heidegger's legal conception can also be found in his analysis of being-guilty, which founds a kind of normative pretension. The reason for this is founded on Heidegger's explanation of the violation of law: making oneself guilty can regulate the ownedness with one another publicly. Consequently, making oneself responsible, by breaking a law as we have thus defined it, can also have the character of "coming to owe something to others" ${ }^{\prime 15}$. This does not happen merely through law-breaking as such, but rather through having the responsibility for another individual thereby becoming endangered in their existence, led astray, or even ruined. In reference to this, Heidegger writes:

This "Being-guilty" as "having debts" [Schulden haben] is a way of Being with Others in the field of concern, as in providing something or bringing it along [...] "Being-guilty" also has the signification of "being responsible for" [schuld sein an] - that is, being the cause or author of something, or even "being the occasion" for something. In this sense of "having responsibility" for something, one can "be guilty" of something without "owing" anything to someone else or coming to "owe" him. On the other hand, one can owe something to another without being responsible for it oneself. Another person can "incur debts" with Others for $\mathrm{me}^{16}$.

Hence, moral guilt is a way of being for Dasein, whereby the violation of law can be considered in parallel, as something that results from being when it is exposed to consciousness. According to Heidegger, if Dasein takes the entity's place, then history becomes fundamental in this connection, because it is the event in which "we act" so that history offers the confrontation in which we are ourselves. Consequently, the basic phenomenon of history has its roots in the facticity of what life is. The analysis of debt sets the law in relation to common understandings: exemplify the common understanding of

13 HEIDEGGER, Martin. Grundbegriffe der aristotelischen Philosophie, GA18, 35.

14 PERRIN, Christophe, and BRogan, Walter A. "From Metaphysics to the Juridical: Heidegger and the Question of Law." Epoché 19, no. 1 (2014): 87-101.

15 HEIDEGGER, Being and Time, GA2, 282.

16 Ibidem, 327. 
natural law, so that the human being can see itself in thrown-ness and existence. Another way to apply the law is to gain the freedom of Dasein from "Man." This is only possible if Dasein is free and can choose itself.

The following chapter will focus on the function that the law has: namely, a regulative one.

\section{The regulated function of the law among individual and state: a way to reach the Gerechtig-keit?}

The legal position of Husserl and Heidegger seems to go in the same direction: law is used by the state to regulate the life of the individuals as a community. Which instrument do both philosophers use to give the law this kind of function? There might be only one answer to this question: norms.

In this regard, Karl Schuhmann points out that Husserl considers the state as legitims problem: this definition suggests the centrality of the legal analysis in his philosophy as the object of phenomenology ${ }^{17}$. Nevertheless, if this legitim definition pertains to the state in the context of the juridical system, then how is it structured? Einleitung in die Ethik. Vorlesungen Sommersemester 1920-1924 suggests a possible answer to this question. By analyzing the ethical, Husserl addresses his reflection to Hobbes Abhandlung über den Bürger in her connection with the state ${ }^{18}$. Hereby, Husserl recognized, in the state, an "egoistic" form of self-preservation, caused by the particular historical context in which Hobbes lived, namely religious wartime in England. This period was characterized by the condition that every individual was against every other. This kind of representation offers an image of a broken Europe in which the dominium of egoistical interest was covered under religious ideals ${ }^{19}$.

The assumed position Husserl's it not something new in the philosophical juridical tradition; Samuel von Pufendorf, for example, referring to the state of nature, accuses Hobbes for this description that underlines the state of war instead a state of peace ${ }^{20}$, so he breaks completely with its principle in the lure naturali et gentium libri octo. Pufendorf's understanding of the state of nature seems to be similar to the Aristotelian conception

17 schumann Karl, Husserls Staatphilosophie, Freiburg/München: Alber, 1988, 28.

18 Hobbes, Thomas. Thomas Hobbes' Abhandlung über den Bürger. Leipzig: Brockhaus, 1873.

19 “(...) das zerrüttete Europa in der Tat das Bild des Krieges aller gegen alle darbot und einer Allherrschaft egoistischer Interesse unter dem Deckmantel religiöse Ideal”. Cf. HUSSERL, E. : op. cit., 43.

20 KAUFMANN, M.: op. cit., p. 7 
of sociality, namely that the individual misses this character of aggression present under the condition of war in favor of mutually supportiveness, given from the social context in which they find themselves ${ }^{21}$.

Hence, Husserl also takes a critical view of Hobbes by considering this kind of aspect to be soaked by egoisms, a "dominant factor" in the world, and is convinced that even the Hobbesian analysis of the state gives the instrument to access to the ought to [Sollen] of the human being orientated accordingly to their rational faculty. From this conception, we can gather from Husserl's thought about social principles by following the prescriptive rule given by the reason. Meanwhile, Husserl point out that the Hobbesian ethic is founded on the doctrine of the state [Staatlehre], in which the concept of ethical right and its negative form are covered from both juridical rights and un-rights: these cover the principle of the state with the demand for reason ${ }^{22}$. This "ideal" reference, namely of Husserl's thought to the Hobbesian doctrine of a rational state, actually gives the individual the possibility to discover their voluntarist conception to socialize, even if their life remains subjugated to the law itself. The core of this demand is given from the structure of the state: this has not been considered according to its casual factual condition, rather it should extract the same content of law from reason ${ }^{23}$. However, Hobbes' theory gives Husserl the instrument by which to understand the prescriptive forms of law as a critique of the state itself. This is the reason why there is a correspondence among laws and reason, since laws became the instrument through which it is present a regulative function.

Further, in the Vorlesungen über Ethik und Wertlehre 1908-1914 Husserl completes his juridical analysis by explaining that a norm does not imply a correspondence with human action, because the natural process has to be considered by following the law of nature. Instead, the individual's action is based on the norms, that guides its active self $^{24}$. From here it might also be possible to deduce that the meaning of law cannot be reduced from a rationalistic perspective, but it has to be inserted into the context of society; by this, Husserl intends firstly a contractual one, as long as it depends on the voluntary action of human beings, grounded in their will. For this purpose, people should be able to voluntarily follow their rational considerations and the complexities of this

21 RoLIN, Jan. "Der Ursprung des Staates: Die Naturrechtlich-rechtsphilosophische Legitimation von Staat und Staatsgewalt im Deutschland des 18. Und 19. Jahrhunderts". Grundlagen Der Rechtswissenschaft 4. Tübingen: Mohr Siebeck, 2005, 20.

22 Cf. HUSSERL, E.: op. cit., 49.

23 "Nur muss natürlich der Staat nicht der zufällig gewordene faktische Staat sein, sondern durchaus und allein seine bestimmte Gesetzgestalt aus der Vernunft ziehen". Cf. HUSSERL, E. : op. cit., 49.

24 HUSSERL, E. und MELLE, Ullrich (ed). Vorlesungen über Ethik Und Wertlehre 1908-1914. Husserliana 28. Dordrecht: Kluwer, 1988, 27. 
process to reach the corresponding evaluations. Through this principle, we might come to understand the role played by justice: because the individual's condition is given through a community, on which the same human being as an individual depends, it is fundamental for the condition of justice that this involve consciousness of the role of principle and rules, which guarantees order in society. Society's models ground Husserl's notions of justice and peace.

Heidegger is also convinced that justice assists Dasein in reaching his being in the world in an authentic way. Nevertheless, the same expression "justice" becomes a fundamental word in making the experience of Being, in his reflection ${ }^{25}$. All of this is already clear in the Introduction to metaphysics, in which Heidegger focuses on the word Sikn. It is possible to discern its two different contrastive points in his examination, which regard both fittingness [Fug] in the sense of joint and structure [Fuge und Gefüge]. But another meaning can be found in the word $\delta i k n$, one that follows a "juridical moral sense": this second exception, as Heidegger admonishes, means that "the word loses its fundamental metaphysical content". What does all of this mean? The answer to this question can be found in the words of Heidegger himself, as he writes

In all its domains and powers, the overwhelming, as regards its powerfulness, is fittingness. Being, phusis, is, as sway, originary gatheredness: the logos. Being is fittingness that enjoins: $\delta i \kappa \eta^{26}$.

Thus, the גóyos means "saying" and not as "ratio", inasmuch it represents the Being, thereby obtaining a juridical meaning, because it designates a way in which the relation

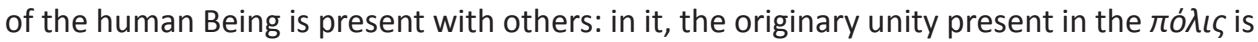
subtended ${ }^{27}$. However, the $\lambda o ́$ yo $\varsigma$ is also an object of the right self, as Heidegger underlines. The word right acts as a helps-word [Hilfswort] and indicates the question of $\delta ı \delta$ óvalv $\delta i k \eta v$, so that the problem belongs on the part of the right [Recht geben] ${ }^{28}$. Additionally, that the word right contains a direction, as Heidegger mentions, it represents fittingness.

This is the reason why there is a discrepancy concerning the results of the experience that the individual has of justice: this concerns the juridical and moral terms and follows

25 Cf. SORDINI, A. "Il problema della giustizia. Dike e Gerechtigkeit", in Fenomenologia e società, $1988,39$.

26 HeIDEGGER, Martin. Introduction to Metaphysics. Nota Bene Books. New Haven (Conn.): Yale University, 2000, 212.

27 Ibidem, 140.

28 HEIDEGGER, Martin, and SCHÜSSLER, Ingeborg. Der Spruch Des Anaximander. Frankfurt Am Main: Klostermann, 2010, 182. 
the established opposition ${ }^{29}$ between the being and the ought to. It might be argued, then, that Heidegger interprets the word justice in its original meaning as $\delta i k \eta$, because he aims to clarify that it is possible to find a connection with the Being through this word. Indeed, it names: "Being with reference to the essentially appropriate articulation of all being" ${ }^{\prime 30}$. However, what is the reason why this connection among justice and Being has this peculiar meaning? This question leads to questions about the rule of law, because Heidegger identifies the knowledge of $\delta i k \eta$ "of the articulating laws of the Being of beings" in his philosophy. Heidegger exemplifies his personals point of view by using Plato's standpoint, as contained in Republic which proffers that "it is essentially necessary that philosophers be the rules" ${ }^{\prime 31}$. The essential knowledge has to be the grounds for the community's behaviour -this is considered by Heidegger as the "order of being" in which the community founds herself on its own basis and does not have to adopt standards from any other's order. This is what Heidegger recognised as the "juridical aspect" of knowledge, in which "unconstrained self-grounding of historical Dasein places itself"32.

Although, the concept of justice finds a connection with the meaning of vouós in the

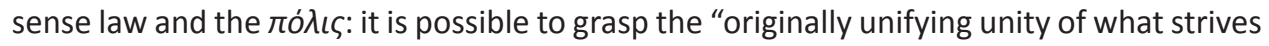
in confrontation" through these terms, as well as its regulative function ${ }^{33}$. The meaning that Heidegger has in mind, something he obviously poses in contraposition with the concept of modern law, is characterised by a general form of regulation community life, that when gathered, as Christoph Perrin observes, can identify the different citizen in its midst ${ }^{34}$. Heidegger's word sustained this observation in his interpretation of Anaximander, by analysing once again the function of $\delta i k \eta$, as "disposing compliance". Nevertheless, compliance "disposes" and is comprised of two properties that Heidegger identified as follows: While one concerns possession because it is a disposal, the other one concerns the prescriptive feature of law, because "it disposes of Being by giving the law to Being"35. So, it might be argued that the law has a regulative function for Heidegger, because it regulates not only the Being of Dasein but also the life of the state. But how might the individual live in this system?

29 PERRIN, op. cit: 12.

30 Cf. HEIDEGGER, M. Nietzsche. New York (N.Y.): Harper and Row, 1979, 166.

$31 \mathrm{lbidem}$.

32 Ibidem.

33 HEIDEGGER, M. op. cit., 9.

34 PERRIN C. op. cit., 11.

35 HEIDEgGeR, Martin and ROJCEWICZ, Richard (ed). The Beginnings of Western Philosophy: Interpretations of Anaximander and Parmenides. Studies in Continental Thought. Bloomington: Indiana University Press, 2015, 123. 
The following chapter will focus on the answer to this question. Thus, it will be clear how the ethical grounds the individual's orientation in the world for both Husserl and Heidegger.

\section{The practical view of ethic: a topological attitude}

In which way ought individuals live? This question seems to be central in the philosophical reflections of Heidegger and Husserl and it grounds the attitude that the individual assumes by living in the world. Both philosophers develop an ethical system founded on the conviction that the ethical serves as an orientation in the world. Whether or this is something theoretical, that follows the principle the $\vartheta \varepsilon \omega \rho \varepsilon \dot{ } \omega$, it does guide the human being in his social life practically. Although, is it not common to think of either philosopher as "ethical thinkers" in the strict sense, their ethical analysis constitutes a central motif of their philosophical production nevertheless. For Husserl, as Ullrich Melle reminds is, an earlier phase and a later phase of ethics can be distinguished, with regards to his pre-war and post-war life ${ }^{36}$. The reason given for this is Husserl's personal experience of the First World War which took a heavy toll and involved a great deal of personal consequences and suffering. As the protagonist of these event, his experience is reflected in the ethical development that can be found in his works.

The young Heidegger too confronted the First World War and its consequences; his thought can also be distinguished in terms of "two ethics", dating from before and after the publication of Being and time (1927). Both ethics are upheld following the same standpoint: a moral connotation appertains to the openness of Dasein, which influences his action in the world. While in his first reflection Heidegger intended the ethical according to its original Greek translation as "Ethos", a place in which the human being can reside, the second moment of his reflection advocated a variety of moral voluntarism, in which a moral authority arise founded upon the free and resolute choice of individuals ${ }^{37}$.

While clarifying the ethical in Husserl's work, Sophie Loidolt rightly observes that the first attempt of Husserl's project is to develop an ethic as a guiding principal for logic; this is reflected in her division of the formal and material, in a-aprioristic and a-posteriori forms respectively ${ }^{38}$. The logical norms, therefore, correspond to logical acts, while norms

36 Cf. MELLE, Ullrich. "The Development of Husserl's Ethics". Etudes Phénoménologiques 7, no. 13 (1991): 115.

37 PHILIPSE, Herman. “Heidegger and ethics." Inquiry 42.3-4 (1999): 439.

38 SOPHIE, L. op. cit. 148. 
of value correspond to the values act [wertenden Akten] ${ }^{39}$. Thus, we might ask how spread out the ethic is; well, Husserl's conception of ethic is founded on an ethical subject. This ethical subject is identified by Husserl as "I" [Ich] obtains a self-determination through his behavior. Thus, Husserl aims to clarify the way in which this "I" realizes itself; this is far from a naive act and considers voluntarism as a pure good, whereby the ambition persists to became a "new I"40. De facto, the "ethical-I" defines good-willing [gut-wollendes]. Finally, if this reflective judge is at the same time a kind of self-evaluation, then what happens to Otherness, the Autrui as Levinas defines it, in this kind of reflection that grounds the society? Husserl answers this question again in a very precisely way, because he argues that the otherness as I-subjects [Ichsubjekte] and subjects of their "I-acts" [ichakte] gives an image of the social morality that correspondents to the I-you [ich-du] determination, in which it presents other's moral renovations and social-ethical effectiveness. This "I" is a conscious subject of the moral community and he is active in $\mathrm{it}^{41}$. In this I-life, Husserl differentiates three intentional classes of acts, which leak out from the prescribed character of reason in the form of norms. Husserl remarks that the intellectual act does not incorporate judgmental acts ${ }^{42}$, but as Ullrich Melle points out, in these classes we experienced and know the object in their categorical determination. Hence, in the class of feeling acts, we-experiences the value-determination of an object; finally, in the class of will acts, it might decide in favor of determinate goals and action ${ }^{43}$.

Husserl's post war ethics focuses on the renewal of the individual, from which it can be distinguished the dual notions of "wilfully" and the "formed life" 44 . Hence, his changing of perspective, since his reflection on ethic is no longer founded on the individual, -rather it is focused on the meaning of community, figure out the subject as a cum-structure, in which the individuals are each other togethers. Hereby, practical reason is used to renovate their life: this idea depends on the attitude of the ethical individual.

39 Cf. HUSSERL, E. and MELLE, Ullrich. Vorlesungen über Ethik Und Wertlehre 1908-1914. Husserliana 28. Dordrecht: Kluwer, 1988, 267.

40 Cf. HUSSERL, E. and PEUCKER, Henning. Einleitung in Die Ethik : Vorlesungen Sommersemester 1920 Und 1924. Husserliana 37. Dordrecht: Kluwer, 2004, 163.

41 Ibidem, 163.

42 Cf. HUSSERL, E. and MELLE, Ullrich. Vorlesungen über Ethik Und Wertlehre 1908-1914. Husserliana 28. Dordrecht: Kluwer, 1988, 295.

43 MELle, Ullrich. "Husserl's Personalist Ethics." Husserl Studies 23, no. 1 (2007): 4.

44 HUSSERL, Edmund, NENON, Thomas, and Sepp, Hans Rainer. Aufsätze Und Vorträge 1922-1937. Husserliana 27. Dordrecht: Kluwer, 1989, 20. 
In a certain similarity to Husserl in his analysis of meaning of $\eta \vartheta \circ \varsigma$, what corresponds to "the Being of human" [Seins des Menschen] ${ }^{45}$, Heidegger comes back to the Greek's tradition. In line with this, Heidegger shows how the $\eta \vartheta 0 \varsigma$ represents the highest [das Höchste] from the human to whom he aspires in the course of its life. Hence, the same $\eta \vartheta \circ \varsigma$ is posed as condition for the sense of the world: mutatis mutandis the ethically life does not involve such considerations, according a modern meaning as alternative suggests to the Greeks; instead, the $\eta \vartheta o \varsigma$ shows the compliance possibility of Dasein to exist ${ }^{46}$.

By referring to Aristotle in Basic concepts of Aristotelian philosophy Heidegger clarifies the connection among language (through Aristotle Rhetoric) and the meaning of the ethical. In the incipit of this paragraph $\$ 16$, entitled "Das $\eta \vartheta o \varsigma$ und das $\pi \alpha \dot{\vartheta} \circ \varsigma$ als

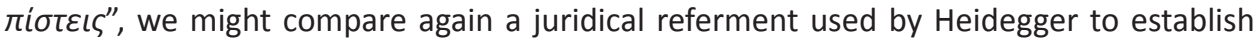
a contrast among the topic of the ordinary discourse before the court and what it is to consider "habitually as object an object of deliberation"47. Hence, as Heidegger argues, it might be distinguished among a kind of speech that can be situated on the side of

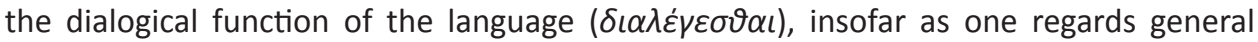
opinion in opposition to general view, while the other, in opposition to this the general view, cultivates a definite view for its purpose. So that das $\eta \vartheta \circ \varsigma$ and das $\pi \dot{\alpha} \vartheta \circ \varsigma$ can be

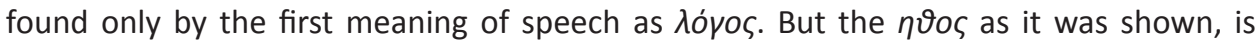
also what examines to the possibility of the Being of the human; so how does Heidegger properly intend this word? To answer this question, we might turn to Being and Time. That Heidegger focuses on this aspect give a particular indication: What he refers to as formal ethics, in turn, operates on the basis of quite different structures, since this justifies the guidance of the ontological constitution of existence, insofar as it bears the responsibility for its being-in-the-world. Specifically, it is important to capture that ethics in its traditional sense still falls under the doctrine of morals. For this very reason, Heidegger distinguishes two conceptions of ethics: a substantive and a formal ethics of values, the "unspoken underlying" which "are disappointed by conscience" 48 . By listening to the conscience, one loses the substantive ethics of values: when existence hears the call, it mutates into actual action that goes up and implies the loss of its meaning.

What Heidegger determined as formal ethics is structured differently because it establishes the guidelines of the ontological constitution of existence, insofar as it-inthe-world has a responsibility for it. If its existence accepts this ethical contour, but also

45 HeIDEGGER, Martin. Platon: Sophistes, GA19, 178.

46 Ibidem.

47 HEIDEGGER, Martin. Grundbegriffe der aristotelischen Philosophie, GA18, 161.

48 Cf. HEIDEGGER, Martin. Being and Time, GA2, 294 
dictates that this standing ethics can be seen at an existential level, then the consequences of this process in Heidegger can be taken out: It is instead about finding out their formal settings in the fundamental ontology.

Hence, it does not come as a surprise that Heidegger considers the conception of privation and lack as "already insufficient" of the phenomenon of guilt, what becomes an indication of the morality at all, in which the moral good and bad are founded ${ }^{49}$. So, the malum as privation boni ${ }^{50}$ serves Heidegger to show how only the formal consideration of ethic can be followed in order to hold it for moral use, because the human, as autonomy essence, is not immediately a Being-good [Gutsein]; instead, he aspires to reach the $\operatorname{good}^{51}$.

That is the reason why one's "wanting-to-have-a-consciousness" means "taking-over of that essential consciousnesseses that the original existential within which alone the existential possibility of being good' subsists" ${ }^{\prime 2}$. The condition of Dasein is to choose itself by acting in the world, as Ann Kuhn remarks ${ }^{53}$; this implies lastly an assumption of a certain grade of responsibility by conduct its life. Rather, if the individual finds itself in an autonomous field of action, then he develops an ability of the world-folder. So, it might be argued that Dasein as "subject" should be interpreted according to its practice and theoretical unity. So, just as in the natural law, Dasein wants to obtain the "law" that makes it possible to release itself from the inauthentic way of life.

This kind of analysis develops further in Heidegger's ethic of "post-Being and Time". Hence, Heidegger poses ethics and logics at the same level, because, "Logic and ethics both refer to human behavior and its lawfulness" ${ }^{\prime 54}$. That the ethic refers to the conduct of the human hints that it might be practiced to gain the good. In Heidegger's words "what human character and behavior comport themselves toward, is the good"55. But how can one intend the good? The good do not found a kind of set of values which are attached to the externality of the Being-human, because the risk that might be incurred is that using these already establish values will define a code of conduct and is, as Heidegger

49 Cf. IRLEnborn, Bernd. Der Ingrimm Des Aufruhrs: Heidegger Und Das Problem des Bösen. Passagen Philosophie. Wien: Passagen, 2000, 79.

50 HEIDEGGER, M. Being and Time, 332.

51 KUHN, Ann. Das Wertproblem in Den Frühwerken Martin Heideggers Und Sein Und Zeit. S.I: S.n., 1968, 117.

52 HEIDEGGER, M. Being and Time, 334.

53 Ibidem

54 HEIDEGGER, M. Nietzsche, GA6, 92.

55 Ibidem 
explained, something that "deposits this thing into an empty space" ${ }^{56}$. Instead, values acquire another kind of meaning recognized from Heidegger in the action of human self ${ }^{57}$. The basis for the determination of action is once again the law; this is why "reason" is free to give itself and can identify with respect to something moral. The ontological contour of that remains being in the world. Heidegger specified that this is not intended as the aggregate of being-ness, but it instead represents its order: this is why, in the second ethic, it is impossible to talk about a "situation ethic" as something locative. In contrast to that, Heidegger tries to develop an ethical view which finds its foundation in liberty and the regulation of the world. All this can also be grasped in Heidegger's interpretation of Kant; in it, Heidegger points out that the practical and theoretical reason are rooted in the context of the imagination ${ }^{58}$. In this, it is possible to grasp the sensation of attention, and the transcendental structure of the moral self. Although only the origin of practical reason, from the transcendental imagination, lends itself to understanding, or at least this is how Heidegger has explained it:

Die Achtung für das Gesetz konstituiert vielmehr erst die Möglichkeit der Handlung. Die Achtung vor (...) ist die Art und Weise, in der uns das Gesetz allererst zugänglich wird. Darin liegt zugleich: dieses Gefühl der Achtung für das Gesetz dient auch, wie Kant sich ausdrückt, nicht zur "Gründung" des Gesetzes ${ }^{59}$.

This analysis of Kant serves Heidegger's explanation that, as Walter Heinemann remarks, the human Being has to accept his finitude. This kind of reflection is also the way to read the question "What should I do?", the answers to which result in very many complications for a human being which has not satisfied fully his potential in life, since his "time" is limited ${ }^{60}$. However, this cannot be asked about the finitude of Dasein, because in view of Heidegger's analysis this becomes a question of metaphysics connected to the (un)dendless of the human being ${ }^{61}$. Heidegger focuses on this point also means

56 HEIDEGGER, Martin. Introduction to Metaphysics. Nota Bene Books. New Haven (Conn.): Yale University, 2000, 175.

57 "Insofern das Wesen der Subjektivität des Subjektes in seiner Personalität liegt, diese aber gleichbedeutend ist mit der moralischen Vernunft, mußte sich der Vernunftcharakter der reinen Erkenntnis und des Handelns verfestigen". HEIDEGGER Martin. Kant und das Problem der Metaphysik, GA3, 168.

58 Ibidem $\S 30$.

59 Ibidem, 158.

60 heInemann, Walter. Die Relevanz Der Philosophie Martin Heideggers Für Das Rechtsdenken. S.I: S.n., 1970, 227.

61 HeIDEGGER Martin. Kant und das Problem der Metaphysik, GA3, 197. 
that to understand his critics of the material critique of value, because the action of the human remains of capital importance to Heidegger, since through that the human beings as possibility can realize themselves; it is possible by acting in the world to create the disclosedness, "da", in the context of his resoluteness, which is characterized by the difference among the theoretical and practical definition of the action itself ${ }^{62}$. Even this action makes Dasein possible -and here we might find a connection with the pre-Being time ethic- to realize itself as free Beings able to act in the world.

62 heInemann, Walter. Die Relevanz Der Philosophie Martin Heideggers Für Das Rechtsdenken. S.I: S.n., 1970, 229. 